KAWISTARA

VOLUME 3

No. 2, 17 Agustus 2013

Halaman 117-226

\title{
Resensi
}

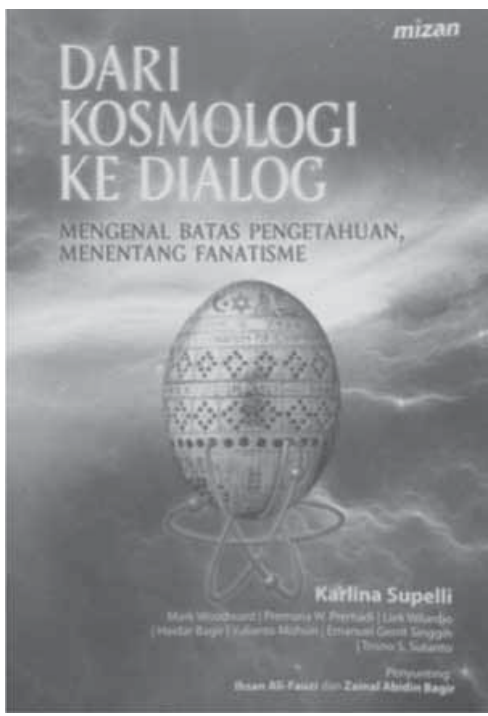

\section{FANATISME, EKTREMISME, DAN PENYINGKIRAN CIRI ANTROPOLOGIS PENGETAHUAN}

Judul Buku

Penulis

Penerbit

Tebal

Najiyah Martiam*
: Dari Kosmologi ke Dialog: Mengenal Batas

Pengetahuan, Menentang Fanatisme

: Karlina Supelli, dkk.

: Mizan Publika, Jakarta 2011.

: 279 hal.
Kapankah sebuah keyakinan berubah menjadi dogmatisme? Seseorang menjadi dogmatis ketika memaksakan keyakinannya kepada pihak lain dengan menggunakan kekuatan-kekuatan institusional, dan ketika ambisinya atas suatu keyakinan menjadi totaliter sehingga menutup faktatif keberagaman penafsiran (hal. 238).

\section{PENGANTAR}

Inilah penjelasan KarlinaSupelli, seorang atrononom dan filosof perempuan pertama Indonesia, mengenai perlunya seorang ilmuwan atau agamawan mempunyai keyakinan yang teguh, baik keyakinan agama atau keyakinan intelektual, tetapi tak terjebak pada dogmatisme keduanya. Menurut Supelli sikap dogmatis inilah yang melahirkan fanatisme dan ektrimisme yang pada gilirannya akan memunculkan tindakan kekerasan dan kebrutalan, baik atas nama agama maupun ilmu pengetahuan. Fenomena kekerasan atas nama agama yang mewarnai cuaca kultural Indonesia akhir-akhir ini dilihat Supelli sebagai

Prodi Agama dan Lintas Budaya, Sekolah Pascasarjana, UGM gejala fanatisme dan ekstremisme yang akan menghalangi kehidupan harmonis di masyarakatyang bhinneka. Gejalaini ditandai oleh kecenderungan pada pemutlakan yang mengarah pada dogmatisme pengetahuan khsusunya agama. Melalui penalaran kosmologi dan filsafat yang menjadi bidang keahliannya ia menawarkan pendekatan epistemologis untuk memahami bagaimana gejala ini dapat terjadi dan diatasi.

Buku ini merupakan orasi ilmiah yang disampaikan Karlina Supelli di Nurcholish Majid Memorial Lecture, di Paramadina pada tahun 2010 yang kemudian diberi tanggapapan oleh beberapa intelektual dari berbagai bidang seperti antropolog, fisikawan, agamawan, astronom, filsuf, pakar sains dan teknologi dan aktivis lintas iman yang kemudian dikomentari balik oleh Supelli sehingga perspektif di dalam buku ini semakin kaya.

Penyingkiran ciri antropologis yang intrinsik pada laku mengetahui menurut Supelli merupakan akar dari munculnya gejala fanatisme dan ekstremisme itu. Ciri antropologis pengetahuan ini dipahami 
sebagai pengetahuan yang tidak dapat sepenuhnya dipahamijika tidak menyertakan manusia sebagai pelaku pengetahuan itu sendiri. Selain karena pelaku pengetahuan terikat oleh konteks sosial-budayanya, realitas itu sendiri memiliki banyak wajah, yang tampilannya akan sangat tergantung pada pertanyaan yang diajukan, instrumen yang dipilih untuk memahaminya, dan tata simbolik yang dibangun untuk mengekpresikannya; sehingga klaim mutlak akan kebenaran apapun, baik agama maupun sains, akan tampak sebagai kepongahan alihalih pernyataan kebenaran yang meyakinkan. Oleh karena itu, bagi Supelli, peluang terjadinya dialog antara sains, filsafat dan agama akan terbuka jika, dan hanya jika, ciri antropologis pengetahuan ini dihargai secara memadai (hal. 22).

Lalu bagaimana kajian kosmologi menjelaskangejalafanatismedanekstremisme agama? Ketegangan antara sains dan agama yang terjadi selama ini menurut Supelli karena keduanya sama-sama menyingkirkan ciri antropologis yang sebenarnya embeded pada setiap laku mengetahui. Di masa lalu orang-orang menyingkirkan ciri antropologis-antropo-sosial pengetahuan supaya dapat mengklaim kebenaran ilmu demi berhubungan dengan kekuasaan. Di masa kini ciri antropologis-antropo-sosial itu disingkirkan agar orang bisa mendaku tahu tentang tuhan dan bahkan tahu apa yang dimaui tuhan, yang pada gilirannya agar dapat mensahihkan kekerasan untuk menindas apapun yang dianggap berbeda. Dalam bahasa Supelli, "Agamawan menjadi moralis dan pengalaman religius diciutkan ke kode-kode perilaku yang secara dogmatik bertumpu pada penafsiran tunggal" (hal. 75). Melalui kajian kosmologi Supelli mengajak baik sains dan agama untuk berendah hati dalam melakoni laku mengetahui.

\section{PEMBAHASAN}

\section{Kosmologi dan Batas Pengetahuan}

Setidaknya ada tiga alasan mengapa kosmologi ia anggap pas untuk menjelaskan bagaimana sains, filsafat, dan agama perlu berdialog agar tidak terjebak pada dogmatisme. Pertama, kosmologi, filsafat dan agama sama-sama mencoba mencari jawaban atas pertanyaan paling purba manusia yaitu asal-usul. Kedua, kosmologi merupakan bidang ilmu yang menurutnya terletak diperbatasan karena menggunakan data dan pendekatan yang beragam tanpa batasan metodologi yang ketat sehingga membuka peluang tidak hanya pendekatan multidisiplin atau lintas disiplin, tetapi juga transdisiplin dalam memahami problemproblem mendasar yang interpretasinya beririsan dengan berbagai bidang pengalaman manusia. Ketiga, kosmologi adalah sains yang unik karena sejauh ini tak ada alam semesta lain yang diketahui.

Kajian tentang alam semesta atau kosmologi menunjukkan bahwa manusia sebagai pelaku pengetahuan tentang alam semesta pada akhirnya menjadi batas dari pengetahuan tentang alam semesta itu sendiri. Artinya mustahil untuk memahami alam semesta sepenuhnya tanpa menyertakan manusia dalam syarat metodologisnya. Data-data empiris materi-energi dari hasil pengamatan dan dugaan masih menyisakan misteri yang begitu besar. Setidaknya data tagihan materi-energi skala besar yang dikumpulkan dalam beberapa tahun terakhir menunjukkan bahwa hanya $5 \%$ kandungan alam semesta yang bisa diketahui karena berupai energi konvensional yang bisa diketahui dan diamati melalui berbagai panjang gelombang. Akan tetapi, $23 \%$ lainnya berupa materi gelap dingin (cold dark matter) alias dugaan-dugaan yang dapat diprediksi. Sisanya sebanyak $72 \%$ adalah energi gelap (dark energy). Disebut energi gelap karena ia belum mampu dijelaskan oleh kosmolog. Ini menunjukkan bahwa manusia sebagai yang mengamati alam semesta mempunyai keterbatasan spasio-temporal. Artinya tidak semua alam semesta dapat diamati karena keterbatasan jangkauan hukum-hukum fisika. Akibatnya cakrawala konseptual pengetahuan pun ikut terbatasi sehingga menyisakan banyak pertanyaan tak terjawab. Lalu bagaimana melampaui keterbatasan 
ini? Supelli mengajak untuk bertandang ke rumah filsafat di mana intuisi dan imaginasi diakui sebagai elemen subjektif pengetahuan. Menurutnya kosmologi menjadi mungkin jika ilmuwan dapat membangun imaginasi dan menggunakan intusi di samping tilikan dari pengalaman-pengalamannya tanpa terpenjara oleh aturan-aturan metode ilmiah, walaupun tetap dituntut setia pada komitmen empiris dan koherensi konspetualnya.

Dalam kosmologi imaginasi memungkinkan sistesis antara pemahaman dan alam semesta sebagai keseluruhan. Suatu sintesis untuk menemukan asas yang akan mempersatukan kemiripan-kemiripan yang tersembunyi yang barangkali ada di belakang senampakan. Suatu sisntesis dalam upaya menemu ulang alam semesta dan mengonstuksikannya ke dalam teori. Suatu sintesis yang mencoba menjangkau mekanisme tersembunyi yang menghasilkan gejala, tetapi yang tak mungkin dapat kita bayangkan "kecuali menambahkan hal-hal yang tidak relevan (bagi pembentukan pengetahuan ilmiah).

Dengan menyertakan manusia sebagai syarat metodologisnya, dengan segala kapasitas imaginasi, pengalaman, dan penafsirannya dalam memahami alam semesta, maka alam semesta terbagi dua yaitu, alam semesta (kosmologi k kecil) yang teramati dan alam semesta (Kosmologi K besar) yang tak terjangkau pencerapan manusia. Kosmologi ini melampaui semua bahasa dan penandaan. Ia hanya bisa dipahami jika dan hanya jika pelaku pengetahuan bersedia melampaui tataran empiris dan konseptual yang kerap tak memberi tempat pada keragaman pengalaman manusia karena tuntutan objektivitas dan rasionalitas ilmu pengetahuan. Jika kosmologi merupakan pengetahuan yang berbasis data yang diperkuat oleh metode verifikasi/ falsifikasi, maka Kosmologi adalah perkara penafsiran atas pengalaman manusia yang tak terkatakan yang seringkali didasari oleh wahyu. Yang seringkali tidak disadari dan jadi sumber masalah bahwa apapun yang telah dikatakan mengenai kosmologi (data ilmiah) atau pun Kosmologi (wahyu) sudah melibatkan penafsiran manusia didalamnya.

Segala bentuk penafsiran menurut Supelli merupakan proses dialektik antara dugaan dan peneguhan sehingga tak ada hasil akhir yang defenitif karena akan selalu ada penafsiran baru terhadap pengalaman. Oleh karena itu kesahihan penafsiran tidak ditentukan oleh data empiris melainkan oleh tafsir lain yang jadi tandingannya. Sehingga kesahihan penafsiran sebenarnya lebih ke perkara argumentatif bukan data empiris.

\section{Bahasa dan Konflik Penafsiran}

Bahasa sebagai salah satu gejala yang muncul mencolok diabad ke-20 telah mengalami pergeseran dari sekedar medium menyampaikan pesan menjadi syarat bagi kemungkinan untuk memahami realitas. Di era penafsiran (the age of interpretation) fakta sudah tidak ada, yang ada hanya penafsiran, yang sebenarnya juga adalah hasil tafsiran. Yang menjadi masalah adalah ketika bahasa terjerembab pada pemutlakan. Bahasa sudah kehilangan rujukan selain pada dirinya sendiri. Artinya konteks bahasa sudah menghilang sehingga makna ditarik dari bahasa itu sendiri. Masalah muncul ketika ada pendakuan otoritas kesahihan penafsiran, ditambah pendakuan adanya identitas antara kebenaran dan otoritas penafsiran.

Inilah menurut Supelli yang dominan pada cuaca kultural Indonesia belakangan ini. Ciri antropologis pengetahuan disingkirkan agar orang dapat mengklaim bahwa merekalah yang paling tahu tentang tuhan dan kehendak tuhan. Mereka menafsirkan realitas secara tunggal dan persepsi diandaikan hanya bergantung pada relasinya dengan realitas yang tunggal itu, sehingga cenderung hitam putih melihat kenyataan. Begitu manusia mengklaim tahu tentang tuhan dia sebenarnya sudah menjadi Tuhan itu sendiri yang dipertaruhkan melalui berbagai epistemologi (laku mengetahui). Padahal epitemologi mengandaikan adanya ciri antropologis dalam laku mengetahui. 


\section{Pendekatan Trans-disiplin}

Untuk mengatasi ketagangan antara makna dan penafsiran Supelli menawarkan pendekatan trans-disiplin. Pendekatan ilmuilmu selama ini menurutnya membawa ke dikotomi antara penjelasan dan penafsiran, dan tidak membawa keluar dari resiko dogmatisasi pengetahuan dan pemutlakan penafsiran serta skeptisisme nalar. Pendekatan lintas disiplin hanya meminjam paradigm dari satu bidang ke bidang lain. Sementara pendekatan multidisiplin yang melibatkan dua atau lebih bidang untuk mengumpulkan perspektif yang berbeda juga tidak menghasilakn pertukaran konseptual, kombinasi, atau integrasi yang memadai untuk memahami kerumitan gejala. Yang dibutuhkan sebenarnya adalah cara bernalar trans-disiplin yaitu penalaran yang tidak mengandaikan adanya penyatuan lewat konvergensi epitemologis ataupun mengandaikan bahwa satu bidang terisolasi dari bidang lainnya.

"Penalaran ini terbuka terhadap ketakpastian pengetahuan dan penafsiran karena keseluruhan dipertimbangkan bukan saja lebih besar dari bagian-bagiannya, tetapi juga punya corak yang berbeda yang belum pernah diketahui" (hal. 78).

\section{SIMPULAN}

Kosmologi merupakan bahasan yang rumit dan penuh bahasa teknis yang tak mudah dipahami, tetapi Supelli berhasil menyampaikannya dengan mudah, indah dan mengalir sehingga runtutan arguemntasinya mudah diikuti. Ia dengan cantik menjalin sains, filsafat dan sastra menjadi sajian pengetahuan yang menawan. Dengan anggun ia menunjukkan bagaimana pengetahuan tentang alam semesta menemui batas-batasnya sehingga dibutuhkan lompatan pada disiplin ilmu lain untuk membantu menjelaskan apa yang tak terjelaskan melalui laku mengetahui lewat penalaran empiris. Manusia sebagai pelaku pengetahuan mempunyai keterbatasan spasio-temporal yang menghalanginya untuk mengetahui realitas alam semesta secara utuh sehingga butuh sumbangan penjelasan dari disiplin ilmu lain untuk mencari jawanan atas apa yang belum terjawab. Inilah menurut Supelli sikap yang mengakui ciri antropologis pengetahuan yang juga berlaku untuk semua laku pengetahuan termasuk agama. 